\title{
Subjective well-being of teachers in modern Russian universities
}

\author{
Lyudmila Skachkova ${ }^{1}$, and Lyudmila Klimenko ${ }^{1 *}$ \\ ${ }^{1}$ Southern Federal University, 344006, Rostov-on-Don, Russia
}

\begin{abstract}
Based on applied research, the article analyzes the indicators of subjective well-being of scientific and pedagogical workers of leading Russian universities. The empirical basis of the study is the results of 8 focus groups with the participation of over 60 university employees and the data of a mass survey of 246 teachers from federal universities. The concept of research on subjective well-being includes the study of a person's cognitive affective assessment of various aspects of his life. The results of the study show that among the university staff surveyed, situational positive emotions prevail over negative feelings, and the level of happiness is slightly higher than the average for the Russian population as a whole. At the level of the cognitive component, quite critical assessments by university teachers of their socio-economic status and working conditions are recorded. However, the importance of economic well-being for university staff is inferior to the values of interesting work, realization of abilities, and recognition of colleagues and students. At the same time, modern education reforms can negatively affect the professional well-being of university employees, as the workload is growing the risks are increasing with the risks of switching to a part-time job or job loss.
\end{abstract}

\section{Introduction}

Teachers and scientists of higher education represent a special socio-professional group that generates a significant contribution to the development of human capital in society. However, in modern Russia, the profession of a scientific and pedagogical worker is characterized by low wages, the need for constant daily development (in connection with research, search and processing of information for classes), high psycho-emotional loads, increased competition for jobs in universities, and the high complexity of administrative and bureaucratic duties.

Meanwhile, many university teachers prefer to come to terms with the above disadvantages and at the same time demonstrate high involvement in the implementation of research and educational projects. Apparently, there are certain factors in the work of

* Corresponding author: lucl@yandex.ru 
university employees that keep them in this profession. And most likely this degree of satisfaction is not related to material values, but to other motives, attitudes and criteria for success in the profession. That is why researchers in the reproduction of human capital in higher education went on to study the subjective well-being of scientific and pedagogical workers (R\&D).

\section{Formulation of the problem}

Since the mid 60 -s of the 20th century, researchers quite intensively began work on the study of subjective well-being (SWB) of citizens, the search for determinants, factors, cause-effect relationships between this category and indicators of economic, social and everyday life of individuals: N Bradburn (Bradburn, 1969), R. Easterlin (Easterlin, 1974), E. Diener (Diener, 2004; 1999), D. Kahneman and A. Deaton (Kahneman, Deaton, 2010), R. Englehart and K. Welzel (Inglehart, Welzel, 2010; 2005), V. Khashchenko (Khashchenko, 2011), etc.

However, to date, a single theoretical concept has not developed in understanding the phenomenon of subjective well-being and relevant methods for measuring it. Currently, a fairly large number of indicators are proposed with which you can determine and measure well-being: the Happy Planet Index, the Gallup-Healthways well-being index, the quality of life study (OECD project), Human Development Index (UN's Human Development Index), index of subjective economic well-being, etc. But in these indices, there is an unclear border between subjective and objective parameters. For example, when measuring the quality of life in various countries, large amounts of objective statistical information are used regarding income, health, life expectancy, etc., that is, in fact, well-being is assessed objectively. At the same time, if the subject of the study is subjective well-being, then it should be a question of how much the individual assesses his level of income, his level of health.

It is also important to point out the paradox of R. Easterlin (Easterlin, 1974). The scientist found that the country's wealth does not directly affect the proportion of people who considered themselves happy. R. Inglehart (Inglehart, Welzel, 2010) in his research on values also found this threshold (a certain saturation point) when economic growth no longer brings a sense of well-being to individuals. These phenomena allow concluding that measuring well-being only by objective indicators (for example, income) does not seem to be true and reasonable.

Thus, in research, the subjective and objective structural components and determinants of well-being are often not bred. In our study, we will focus on studying the well-being of employees of leading Russian universities from the perspective of its subjective measurement by the NDP itself.

\section{Methodology and empirical basis of the study}

The basis of the methodological construct for assessing the subjective well-being of the CPD of Russian universities is based on the following principles: 1) the distinction between subjective and objective measurement of well-being; 2) the allocation of two main components of subjective well-being: affective (the number of negative and positive emotions at a given time, the level of happiness) and cognitive (the individual assesses his well-being); 3) taking into account the complex of determinants of subjective well-being with special consideration of a group of professional factors; 4) the inclusion in the research tools of proven methods and scales to enhance the validity of measurements.

The empirical foundations of the study are: 
1) the results of 8 focus groups with the participation of employees of 5 universities in the South of Russia conducted (in 2018, about 60 people participated in focus group studies);

2) the interim results of a mass survey of academic research work of Russian universities with federal status2 (in 2019, 246 employees of 10 federal universities of the country took part in the survey, the sample of the survey was quota-proportional by gender, age and position).

\section{The affective component of subjective well-being}

Affection Balance Scale (Bradburn, 1969) was included in the toolkit of a sociological survey of the scientific research work of federal universities. The scientist believed that the indicator of happiness is the achievement of a balance between negative and positive influences, the discourses of the behavior of subjects.

Empirical measurements show that among the university staff surveyed, positive emotions prevail over negative feelings. In the past weeks, at the time of the survey, teachers experienced the pleasure of achievement, interest and strong involvement, as well as pride in praise. More than $80 \%$ of respondents did not feel boredom, depression, loneliness. Only $18.5 \%$ of the CPD of federal universities felt absolutely happy, but no more than a tenth of the respondents was unhappy (Table 1).

Table 1. Have you felt anything like this in recent weeks? [\%]

\begin{tabular}{|c|c|c|}
\hline & yes & no \\
\hline \multicolumn{3}{|l|}{ Positive emotions } \\
\hline The pleasure of having achieved or completed something & 86,8 & 13,2 \\
\hline Everything goes as you would like & 39,2 & 60,8 \\
\hline Proud that someone praised me for what $\mathrm{i}$ did & 56,7 & 43,3 \\
\hline Extremely excited about an event or have a strong interest in something & 62,5 & 37,5 \\
\hline I feel absolutely happy & 18,5 & $\mathbf{8 1 , 5}$ \\
\hline \multicolumn{3}{|l|}{ Negative emotions } \\
\hline Feeling anxious, can't sit still & 37,8 & 62,2 \\
\hline Boredom, lack of interest in anything & 16,7 & 83,3 \\
\hline Depressed or very unhappy & 11,0 & 89,0 \\
\hline Strong loneliness or remoteness from other people & 9,2 & 90,8 \\
\hline Upset because someone criticized you & 21,8 & $\mathbf{7 8 , 2}$ \\
\hline
\end{tabular}

According to another scale measuring the general perception of happiness in international studies, teachers of domestic federal universities are on average happier than the population of Russia. So, according to the results of the European Social Survey in 2016, Russians rated this indicator at 6.3 average points on a 10-point scale (this is the lowest indicator in 23 countries that took part in the study, and it does not changed since the survey in 2012). While surveys of university teachers in 2019 recorded a degree of happiness of 7.2 average points (which is comparable to the indicators of Western European countries) (Table 2).

Table 2. Given all aspects of your life, how happy are you? (use a scale from 0 to 10 , where 0 is very unhappy and 10 is very happy), in average scores

\begin{tabular}{|c|c|c|c|c|c|c|}
\hline $\begin{array}{c}\text { 2019 Federal } \\
\text { Universities } \\
\text { of the RF }\end{array}$ & \multicolumn{7}{|c|}{ 2016, European Social Research ${ }^{\mathbf{3}}$} & Ppain & Poland \\
\cline { 2 - 7 } & Russia & Germany & France & Norway & & 7,7 \\
\hline 7,2 & 6,3 & 7,8 & 7,4 & 8,1 & 7,7 & 7,5 \\
\hline
\end{tabular}




\section{The cognitive component of subjective well-being}

The study of the following parameters was laid in the research program for the subjective well-being of teachers of Russian universities: the degree of subjectivity in the design of life strategies, the assessment of freedom, awareness of the value and meaning of professional activity; assessment of the quality of life and professional sphere. Let us dwell on some of the survey results.

Most university teachers are focused on subjectivity in the construction of life strategies. When answering the question "What do you think, what success depends to a greater extent: personally of you (on your efforts, character, diligence, prudence) or on circumstances beyond your control (on the situation in the country, in our city, on the authorities, accidents, good luck, etc.)?" $64.2 \%$ of respondents chose the answer "on me". A fifth of respondents $(20.3 \%)$ believe that success is determined by circumstances beyond their control. It should be noted that, according to the World Values Survey international studies, in countries with developed economies and democratic institutions, ideas about the internal causality of an individual depending on the individual themselves prevail (Inglehart, Welzel, 2005).

The degree of freedom is estimated by the interviewed teachers lower than the level of happiness. NDP of federal universities was proposed to evaluate on a 10-point scale to what extent they feel free. The survey materials recorded 6.1 average points for this position.

Moreover, the income level of university teachers does not fully satisfy their basic needs. Interim results of the study showed that according to the respondents, their salary provides the need for independence and freedom only by 5.8 average points (on a 10-point scale), in material well-being - by 5.5 points, in self-realization - by 5.8 points, in safety by 6.1 points.

If you look at the general panorama of the satisfaction of the interviewed teachers with various aspects of their life, you can see that most of the respondents are satisfied with family relations (8.2 average points), food (8.0), dressing opportunities (7.4) and living conditions (7.2). Least of all university staff is satisfied with financial security (5.9), situation at work (6.0) and leisure activities (6.4). (Table 3)

Table 3. Evaluate different aspects of your life (use a scale from 0 to 10 , where 0 is absolute dissatisfaction, and 10 is maximum satisfaction), in average scores

\begin{tabular}{|l|c|l|c|}
\hline & $\begin{array}{l}\text { Aver. } \\
\text { point }\end{array}$ & & $\begin{array}{c}\text { Aver. } \\
\text { point }\end{array}$ \\
\hline family relationships & 8,2 & financial security & 5,9 \\
\hline food & 8,0 & situation at work & 6,0 \\
\hline clothes and shoes & 7,4 & leisure activities & 6,4 \\
\hline living conditions & 7,2 & health status & 6,5 \\
\hline position, status in society & 7,2 & place, region of residence & 6,9 \\
\hline level of personal security & 7,1 & ability to chat with friends & 6,9 \\
\hline $\begin{array}{l}\text { the opportunity to obtain the } \\
\text { necessary education and knowledge }\end{array}$ & 7,0 & $\begin{array}{l}\text { the opportunity to realize oneself in the } \\
\text { profession }\end{array}$ & 7,0 \\
\hline
\end{tabular}

The professional sphere plays a significant role in the life of the NDP who participated in the study. Most of the respondents agreed that if they could decide again, they would again choose their current profession (agreement with the approval of 7.4 average points on a 10-point scale). For many, work at the university allows them to show their abilities (7.6), realize their creative potential (7.5), and enjoy respect among colleagues and students (8.0).

On the other hand, not everyone is satisfied with their career prospects at work (5.7 average points), with the ability to make their own decisions about what and how to do (6.5). University professors agree, on average, that the advantages of their profession clearly outweigh the disadvantages (6.6). 
The interviewed employees of federal universities rate the prestige of their profession rather low. Only $14 \%$ of respondents agree that the profession of NDP is prestigious. While the majority of respondents considers that "this is an ordinary profession, not too prestigious, you cannot call it prestigious" $(62.2 \%)$. The salary also probably does not correspond to the volume and complexity of the work that university teachers perform (51.2\% of respondents noted the options "rather do not fit" and completely do not match"$19.5 \%)$.

On the other hand, most CPDs are generally satisfied with their work (agreement with the approval of 7.1 average points on a 10-point scale). And also many respondents agree that they have found their destiny, a place in life (7.5).

Speaking about the attractiveness factors of the academic labor market, this problem was discussed in detail at focus groups with employees of universities in the South of Russia. Research materials show that teachers in the field of higher education are interested in and enjoy the process of teaching and research, work schedules, the possibility of personal and professional development, knowledge transfer. Among the factors pushing out of universities, bureaucracy, the low level of incomes of the CPD, emotional overstrain, unfair competition in the selection of candidates for the extension of labor contracts are most often called. Thus, working conditions in the field of higher education are not attractive, and the main deterrent is vocation work, the mission of generating and transmitting knowledge (Skachkova, Shchetinina, Kryachko, 2018).

Systemic reforms of education in Russia affect the socio-economic situation of educators (Klimenko, Posukhova, 2018). The results of a mass survey show that $80 \%$ of teachers of federal universities are concerned about the risks of an increase in workload without an increase in salaries. About $60 \%$ of respondents are concerned about the possibility of job loss and / or forced transition to an incomplete share of the rate.

Table 4. How much are you currently concerned about the following occupational risks? [at \%]

\begin{tabular}{|l|c|c|c|c|}
\hline & $\begin{array}{c}\text { Doesn't } \\
\text { bother at all }\end{array}$ & $\begin{array}{c}\text { Rather, } \\
\text { doesn't } \\
\text { bother }\end{array}$ & $\begin{array}{c}\text { Rather, } \\
\text { bother }\end{array}$ & Bother \\
\hline salary reduction or delay & 18,0 & 29,5 & $\mathbf{3 0 , 3}$ & $\mathbf{2 2 , 1}$ \\
\hline $\begin{array}{l}\text { forced transition to an incomplete } \\
\text { share of the rate }\end{array}$ & 12,3 & 26,2 & $\mathbf{3 0 , 3}$ & $\mathbf{3 1 , 1}$ \\
\hline $\begin{array}{l}\text { increased workload without } \\
\text { increasing salaries }\end{array}$ & 5,7 & 14,6 & $\mathbf{2 9 , 3}$ & $\mathbf{5 0 , 4}$ \\
\hline job loss & 10,6 & 27,6 & $\mathbf{3 1 , 7}$ & $\mathbf{3 0 , 1}$ \\
\hline
\end{tabular}

\section{Conclusion}

The concept of research on subjective well-being includes a cognitive assessment of satisfaction with various aspects of life and the emotional factors of feeling satisfied with life ("effectiveness"). The results of the study show that among the university staff surveyed, situational positive emotions prevail over negative feelings, and the level of happiness is slightly higher than the average for the Russian population. At the level of the cognitive component, quite critical assessments of teachers of their socio-economic status and working conditions are recorded. However, the importance of economic prosperity for the CPD is inferior to the values of interesting work, realization of abilities, creativity, recognition from colleagues and students. The field of higher education is attractive to many because of its involvement in the teaching process and in research, work schedules, and development opportunities. At the same time, modern educational reforms can 
negatively affect the professional well-being of university employees, when reforms result in an increase in workload, risks of switching to a part-time job or job loss.

\section{Acknowledgments}

1. The study is supported by the Russian Foundation for Basic Research, grant No. 18-010-00952.

2. At present, there are 10 federal universities in Russia located in different parts of the country and having autonomous status. The mission of federal universities is the formation and development of competitive human capital in federal districts based on the creation and implementation of innovative services and developments.

3. The research results are available on the official website of the study in Russia http://www.essru.ru and on the official website - http://www.europeansocialsurvey.org

\section{References}

1. N.M. Bradburn, The structure of psychological well-being (Aldine, Chicago, 1969).

2. E. Diener, Seligman M. E. P., Beyond money: Toward an economy of well-being, Psychological Science in the Public Interest, 5, 1-31 (2004).

3. E. Diener, E. Suh, R.E. Lucas, H.L. Smith, Subjective well-being : three decades of progress, Psychological Bulletin, 125(2), 276-302 (1999).

4. R.A. Easterlin, Does Economic Growth Improve the Human Lot? Some Empirical Evidence, Nations and Households in Economic Growth, 89, 89-125 (1974).

5. R.F. Inglehart, C. Welzel, Agency, Values, and Well-Being: A Human Development Model, Social Indicators Research, 97, 43-63 (2010).

6. R. Inglehart, C. Welzel, Modernization, Cultural Change and Democracy: The Human Development Sequence, Cambridge University Press, (2005).

7. D. Kahneman, A. Deaton, High income improves evaluation of life but not emotional well-being, PNAS, 107(38), 16489-16493 (2010).

8. V.A. Khashchenko, Subjective economic well-being and its measurement: questionnaire construction and its validation, Experimental psychology, 4(1), 106-127 (2011). (In Russ.)

9. L.V. Klimenko, O.Y. Posukhova, Professional identity of school teachers in the context of socio-historical dynamics of Russian society, International Journal of Educational Management, 32(5), 813-824 (2018).

10. L.S. Skachkova, D.P. Shchetinina, V.I. Kryachko, Subjective well-being factors of scientific and pedagogical workers: focus groups results, State and municipal management. Scientific notes, 4, 138-146 (2018). (In Russ.) 